\title{
NITRATES IN PLANTS AND SOIL AFTER FERTILIZATION OF GRASS-LEGUME MIXTURES **
}

\author{
Z. Nešić ${ }^{*}$ Z. Tomić, V. Krnjaja, D. Tomašević ${ }^{1}$ \\ ${ }^{1}$ Institute for Animal Husbandry, Belgrade-Zemun, 11080 \\ *Zorica Nešić; e-mail: zonesh@gmail.com \\ ** Original scientific paper-Originalni naučni rad
}

Research was financed by the Ministry of Science of Republic of Serbia within project TR 20005/08 - Rad je finansiran od strane Ministarstva za nauku Republike Srbije u okviru projekta TR 20005/08

Abstract: Nitrates are one of the most frequent utilized forms of $\mathrm{N}$ from soil. Through root they reach stem and leaf where in photosynthetic processes they convert into proteins. Due to exposure to stress situations, and excessive nitrogen fertilization, nitrate accumulation in plant tissues and organs occurs. Also, nitrates can accumulate in harmful concentrations in soil. Nitrates accumulated in plants have harmful effect on animals which consume plants since they cause various health disorders. In variance analysis in both investigation years it was established that fertilization as well as interaction of factors mixture/fertilization had very significant effect on investigated quality parameter, contrary to mixture as single factor. In both investigation years, treatments with $210 \mathrm{kgN} \mathrm{ha}^{-1}$ had the highest nitrate concentration. Content of nitrate nitrogen in soil is increased by fertilization. Objective of the research was to determine nitrate quantities which are accumulated in plants subsequent to $\mathrm{n}$ fertilization and growing in mixtures with other species, as well as to determine nitrate quantities which remain in the soil unutilized, which are potential causes of environment pollution.

Key words: grass-legume mixture, soil, nitrate, fertilizer.

\section{Introduction and literature review}

Agricultural producers want to realize high and stable production of good quality. Therefore mineral fertilizers are applied, primarily $\mathrm{N}$ fertilizers which increase the quantity of $\mathrm{N}$ forms of minerals necessary for plant growth and development. Plants have different needs/requirements in regard to $\mathrm{N}$. 
Especially high quantities of $\mathrm{N}$ are accumulated by plants which are characterized by large vegetative mass (Vojin et al., 2003).

Nitrates are one of the most frequent utilized forms of $\mathrm{N}$ from soil. Through root they reach stem and leaf where in photosynthetic processes they convert into proteins. Due to exposure of plants to stressful situations (drought, warm and dry wind, cloudy and cold weather, frost, plant injuries, etc.) nitrates accumulate in plant tissues and organs, mainly in the bottom third of the stem (Stanton, 2001).

Introduction of high quantities of $\mathrm{N}$ fertilizer can also lead to accumulation of $\mathrm{NO}_{3}^{-}$in plants, but also in soil, which can have negative consequences. From the aspect of soil, accumulated nitrates are being transported from rizosphere by precipitation to underground waters and surface waters and cause pollution. According to EU legislation, allowed quantity of nitrates in underground waters is up to $50 \mathrm{mg} / 1$ (Nitrate Directive- 91/676/EEC). Nitrates accumulated in soil have unfavourable effect on nitrogen fixation in leguminous plants, since they reduce the root surface, as well as number of root nodules (Hannaway and Shuler 1993).

According to Wright and Davidson (1964), nitrates accumulated in plants have harmful effect on animals which consume plants since they cause various health disorders, even deaths (quote Shiel et al., 1999). Agricultural Research Council (1980) states that nitrate concentrations over 3000-5000 ppm are considered as potentially dangerous and must be avoided in certain groups of animals - livestock in gestation, due to incidence of abortions (quote Shiel et al., 1999). However, Stanton (2001) states that forage containing less than 5000 ppm of nitrates is considered as harmless and can be used in nutrition, forage containing from $5000-10000 \mathrm{ppm}$ is considered potentially toxic, and forage containing over $10000 \mathrm{ppm}$ of nitrates is considered as toxic and can not be used in nutrition.

Content of $\mathrm{NO}_{3}{ }^{-}$in plants is in direct relation to content of nitrates in soil (Ilinef, 2000). Introduction of $\mathrm{N}$ to the soil through fertilizers increases the concentration of $\mathrm{NO}_{3}^{-}$in soil solution, which leads to increased intake and accumulation of $\mathrm{NO}_{3}^{-}$in plants, (Petrović, 2003).

Objective of the research was to determine nitrate quantities which are accumulated in plants subsequent to $\mathrm{n}$ fertilization and growing in mixtures with other species, as well as to determine nitrate quantities which remain in the soil unutilized, which are potential causes of environment pollution.

\section{Material and methods}

A two-factor trial was set at the Institute for Animal Husbandry, Belgrade-Zemun during 2003-2004. The first factor in the investigations was 
sward type: pure lucerne and its three mixtures (mixture I, with cocksfoot; mixture II, with cocksfoot and tall fescue; and mixture III with cocksfoot, tall fescue and sainfoin. The second factor was fertilization with four different quantities of $\mathrm{N}\left(0,70,140\right.$ and $\left.210 \mathrm{~kg} \mathrm{~N} \mathrm{ha}^{-1}\right)$. Fertilization was carried out on two occasions during a single year, in 2003 after sowing and after the first cut, and in 2004 at the beginning of vegetation and after the first cut. The nitrate content in the herbage DM of mixtures was investigated as a quality parameter and is presented in this paper as an average value of all cuts in the investigation year. The data were analyzed by analysis of variance for a $4 \times 4$ randomized block design with four blocks, mean values tested with LSD test

The soil on which the trial was set was poor carbonate chernozem, of favourable water, air and thermal regime, and very good granular structure. Chemical characteristics of the soil are presented in Table 1.

Table 1. Chemical characteristics of the soil on which the trial was conducted Tabela 1. hemijske karakteristike zemljišta na kojem je izveden ogled

\begin{tabular}{|l|l|l|l|l|l|l|l|l|}
\hline $\begin{array}{c}\text { Depth/ } \\
\text { Dubina }\end{array}$ & $\mathbf{p H}$ & $\mathbf{p H}$ & $\mathbf{H u m u s}$ & $\mathbf{C a C O}_{\mathbf{3}}$ & $\mathbf{N}$ Total & $\mathbf{N}-\mathbf{N O}_{\mathbf{3}}$ & $\mathbf{P}_{\mathbf{2}} \mathbf{O}_{\mathbf{5}}$ & $\mathbf{K}_{\mathbf{2}} \mathbf{O}$ \\
\hline $\mathbf{c m}$ & $\mathrm{H}_{2} \mathrm{O}$ & $\mathrm{KCl}$ & $\mathrm{g} \mathrm{kg}^{-1}$ & $\mathrm{~g} \mathrm{~kg}^{-1}$ & $\mathrm{mg} \mathrm{kg}^{-1}$ & $\mathrm{mg} \mathrm{kg}^{-1}$ & $\mathrm{mg} \mathrm{kg}^{-1}$ & $\mathrm{mg} \mathrm{kg}^{-1}$ \\
\hline $\mathbf{0 - 2 0}$ & 7.29 & 7.08 & 43.5 & 3.3 & 1975 & 52 & 909 & 162 \\
\hline $\mathbf{2 0 - 4 0}$ & 7.23 & 7.09 & 44.3 & 4.7 & 1938 & 57 & 918 & 165 \\
\hline
\end{tabular}

Average air temperatures during 2003 and 2004 were higher than the long-term average and were recorded as $12,7{ }^{\circ} \mathrm{C}$ and $12,4{ }^{\circ} \mathrm{C}$, respectively. Based on the data on total annual precipitation it can be concluded that 2003 was dry with $551,9 \mathrm{~mm}$ of precipitation, which was $93,3 \mathrm{~mm}$ lower than the average value determined for several years. In 2004, however, the precipitation was as high as $831,6 \mathrm{~mm}$ which had a positive effect on the productive characteristics of plants.

\section{Results and discussion}

Analysis of DM yield and nitrates in plants

In variance analysis in both investigation years it was established that fertilization as well as interaction of factors mixture/fertilization had very significant effect on investigated quality parameter, contrary to mixture as single factor.

In the first year, higher nitrate concentrations in plants by $21,3 \%$ or 459 ppm was determined compared to the second research year (table 2). 
Mixtures had no statistically significant effect on content of nitrates in plants, but it was registered that by combining grasses and legumes in mixture, content of nitrate increases compared to single lucerne crop. Same results were obtained by Shiel et al. (1999), in their investigation of content of nitrate in mixtures where by increase of share of grasses also the nitrate concentration increased. This is interpreted in a way that grass species in mixtures have greater physiological ability for accumulation of higher concentrations of nitrate ions in relation to leguminous plants (Nešić et al., 2007, 2008).

In both years, fertilization had very significant effect on content of $\mathrm{NO}_{3}{ }^{-}$ in plants. With the increase of the quantity of added $\mathrm{N}$, also the content of $\mathrm{NO}_{3}{ }^{-}$ in mixtures increased. Treatments with $210 \mathrm{kgN} \mathrm{ha}^{-1}$ resulted in significantly higher concentration of $\mathrm{NO}_{3}^{-}$compared to other treatments, as well as treatments with 140 and $70 \mathrm{kgN} \mathrm{ha}^{-1}$ compared to treatment without $\mathrm{N}$. For instance, in year 2003, maximum content of $\mathrm{NO}_{3}{ }^{-}$was established in treatment with the highest added quantity of $\mathrm{N}-3401 \mathrm{ppm}$, which was by $185,7 \%$ more compared to treatment without $\mathrm{N}$. In the next research year, treatments with 210 $\mathrm{kg} \mathrm{N} \mathrm{ha}{ }^{-1}$ had maximum concentration of $2847 \mathrm{ppm}$, and treatments without $\mathrm{N}$ minimal of $732 \mathrm{ppm}$ which represents difference of $288,9 \%$. Obtained differences between treatments were at the level of probability of $99 \%$. Totev et al. (1997) and Shiel et al. (1999), also state that content of $\mathrm{NO}_{3}{ }^{-}$in mixtures increases with increase of amount of added nitrogen by fertilization, and that it differs in various cuts.

Interaction of factors in both investigation years showed very significant effect on content of nitrate ion in forage mixtures, and established differences at the level of significance of $p<0,01$ are present within individual mixtures for certain fertilization treatments, and between mixtures.

Based on these results it can be concluded that fertilization, in general, did not induce the increase of nitrate content above the harmful level (Agricultural Research Council, 1980). Exceeding of this limit occurred in some cases depending on the year, cut and treatment. 
Table 2. Content of $\mathrm{NO}_{3}^{-}$(ppm) in DM of sowed grassland depending on the share of lucerne in mixture and $\mathrm{N}$ fertilization in years 2003 and 2004

Tabela 2. Sadržaj $\mathrm{NO}_{3}^{-}(\mathrm{ppm})$ u suvoj materiji sejanog travnjaka u zavisnosti od udela lucerke u smeši i đubrenja $N$ u 2003. i 2004. godini

\begin{tabular}{|c|c|c|c|c|}
\hline \multicolumn{3}{|c|}{ Year/Godina } & 2003 & 2004 \\
\hline Mixtures/Smeše & \multicolumn{2}{|c|}{$\mathbf{N}\left(\mathbf{B}_{\mathbf{n}}\right)$} & $\begin{array}{c}\text { Nitrates/ } \\
\text { Nitrati }\end{array}$ & $\begin{array}{c}\text { Nitrates/ } \\
\text { Nitrati }\end{array}$ \\
\hline \multirow{4}{*}{$\begin{array}{l}\text { Lucerne/ } \\
\text { Lucerka }\end{array}$} & \multicolumn{2}{|c|}{0} & 1054 & 836 \\
\hline & \multicolumn{2}{|c|}{70} & 1694 & 1271 \\
\hline & \multicolumn{2}{|c|}{140} & 1899 & 1875 \\
\hline & \multicolumn{2}{|c|}{210} & 3055 & 2550 \\
\hline \multicolumn{3}{|l|}{ Average/Prosek } & 1926 & 1633 \\
\hline \multirow{4}{*}{$\begin{array}{c}\text { Mix./ } \\
\text { Smeša } \\
\text { I }\end{array}$} & \multicolumn{2}{|c|}{0} & 1175 & 593 \\
\hline & \multicolumn{2}{|c|}{70} & 1350 & 1441 \\
\hline & \multicolumn{2}{|c|}{140} & 2807 & 2167 \\
\hline & \multicolumn{2}{|c|}{210} & 3227 & 2972 \\
\hline \multicolumn{3}{|l|}{ Average/Prosek } & 2140 & 1793 \\
\hline \multirow{4}{*}{$\begin{array}{l}\text { Mix./ } \\
\text { Smeša } \\
\text { II }\end{array}$} & \multicolumn{2}{|c|}{0} & 1317 & 652 \\
\hline & \multicolumn{2}{|c|}{70} & 1939 & 839 \\
\hline & \multirow{2}{*}{\multicolumn{2}{|c|}{$\begin{array}{l}140 \\
210\end{array}$}} & 2366 & 1698 \\
\hline & \multirow{2}{*}{\multicolumn{2}{|c|}{210}} & 3812 & 2386 \\
\hline Average/Prosek & & & 2358 & 1394 \\
\hline \multirow{4}{*}{$\begin{array}{c}\text { Mix./ } \\
\text { Smeša } \\
\text { III }\end{array}$} & \multicolumn{2}{|c|}{0} & 1215 & 846 \\
\hline & \multicolumn{2}{|c|}{70} & 1820 & 1300 \\
\hline & \multicolumn{2}{|c|}{140} & 2227 & 2215 \\
\hline & \multicolumn{2}{|c|}{210} & 3508 & 3479 \\
\hline \multicolumn{3}{|l|}{ Average/Prosek } & 2192 & 1960 \\
\hline \multirow{4}{*}{ Average/Prosek } & \multicolumn{2}{|c|}{0} & 1190 & 732 \\
\hline & \multicolumn{2}{|c|}{70} & 1701 & 1213 \\
\hline & \multicolumn{2}{|c|}{140} & 2325 & 1989 \\
\hline & \multicolumn{2}{|c|}{210} & 3401 & 2847 \\
\hline & & A & 2022,3568 & 1198,0148 \\
\hline & 0,01 & $\mathrm{~B}$ & $886,4897 * *$ & $954,0737 * *$ \\
\hline & & $\mathrm{AB}$ & $2585,1746^{* *}$ & $2073,4136^{* *}$ \\
\hline & & $\mathrm{A}$ & 1334,9628 & 790,8126 \\
\hline & 0,05 & $\mathrm{~B}$ & 654,1704 & 704,0429 \\
\hline & & $\mathrm{AB}$ & 1774,3776 & 1469,8517 \\
\hline
\end{tabular}




\section{Analysis of nitrates in soil}

Content of nitrates in soil subsequent to fertilization at the end of trial is presented in table 3. Content of ammonia and nitrate forms of nitrogen increased in relation to the beginning of trial in average by $52,1 \% \mathrm{NH}_{4}{ }^{+}-\mathrm{N}$ and $40,1 \% \mathrm{NO}_{3}^{-}-\mathrm{N}$.

Content of ammonia nitrogen was the highest in soil on which the mixture II was investigated - $35 \mathrm{ppm}$, and the lowest in mixture III of $19 \mathrm{ppm}$, which is difference of $16 \mathrm{ppm}$. In relation to pure/single lucerne crop, where content of ammonia nitrogen in soil was $26 \mathrm{ppm}$, content of ammonia nitrogen in mixture II was higher by $9 \mathrm{ppm}$, and lower in mixture III by $7 \mathrm{ppm}$.

In treatments without fertilization the highest concentration of $\mathrm{NH}_{4}^{+}-\mathrm{N}$ in soil of $30 \mathrm{ppm}$ was realized, and treatments with $70 \mathrm{kgN} \mathrm{ha}^{-1}$ resulted in the lowest concentration of $26 \mathrm{ppm}$, which is lower by $4 \mathrm{ppm}$.

The highest amount of nitrate nitrogen was determined in mixture I $94 \mathrm{ppm}$, and the lowest in mixture III - $61 \mathrm{ppm}$, which makes the difference of $33 \mathrm{ppm}$. In comparison to pure lucerne crop, where nitrate concentration of 71 ppm in soil was established, in mixture I concentration higher by $23 \mathrm{ppm}$, and in mixture III lower by $10 \mathrm{ppm}$ were established. Content of $\mathrm{NO}_{3}{ }^{-}-\mathrm{N}$ in soil increases with fertilization. The lowest $\mathrm{NO}_{3}{ }^{-}-\mathrm{N}$ was established in treatments without fertilization - $61 \mathrm{ppm}$, and the highest in treatments with $210 \mathrm{kgN} \mathrm{ha}^{-1}$ of $89 \mathrm{ppm}$, which is by $46 \%$ higher compared to the minimum.

According to results of Petrovic et al. (1985) that content of nitrate and ammonia $\mathrm{N}$, in soil type chernozem with intensive agricultural production, is 9,4 and 3,8 ppm, respectively. Andraski and Bundy (2002) obtained results on content of nitrate nitrogen in soil after growing of lucerne on depth of $30 \mathrm{~cm}$ of 10,0 - 43,0 ppm, and Ferguson et al. (2002) of 2,7-14 ppm in soil on depth of $90 \mathrm{~cm}$. Results in stated research indicate that content of this nutrient is high which can represent potential threat and danger of pollution of soil, water and plants with nitrates. It is considered that such high concentrations of $\mathrm{NO}_{3}{ }^{-}$in soil are consequence of application of high quantities of $\mathrm{N}$ mineral fertilizers (Elgersma and Hassink, 1997; Eghball, 2002), as well as accumulation of $\mathrm{N}$ in soil from nitrogen fixation which plants have not utilized. 
Table 3. Chemical analysis of soil depending on the type of mixture and amount of added $N$ fertilizer subsequent to trial in 2004

Tabela 3. Hemijska analiza zemljišta u zavisnosti od vrste smeše i količine dodatog $\mathbf{N}$ đubriva nakon izvođenja ogleda u 2004. godini

\begin{tabular}{|c|c|c|c|c|}
\hline \multirow{2}{*}{$\begin{array}{l}\text { MIXTURE/SME ̌ } \\
\text { A }\end{array}$} & \multirow[t]{2}{*}{$\mathbf{N}$} & $\mathbf{N H}_{4}^{+}$ & $\mathrm{NO}_{3}^{-}$ & \multirow{2}{*}{$\begin{array}{c}\text { Content of } \mathrm{NH}_{4}^{+} \text {and } \\
\mathrm{NO}_{3}^{-} \\
\text {In trial } \\
\text { design/Sadržaj } \\
\mathrm{NH}_{4}^{+}{ }^{+} \mathrm{NO}_{3}^{-} \\
\text {u postavci ogleda }\end{array}$} \\
\hline & & \multicolumn{2}{|c|}{$\mathrm{N} \mathrm{mg} / 1000 \mathrm{~g}(\mathrm{ppm})$} & \\
\hline \multirow{4}{*}{$\begin{array}{l}\text { Lucerne/ } \\
\text { Lucerka }\end{array}$} & 0 & 33 & 62 & \multirow{17}{*}{$18,3 \mathrm{ppm} \mathrm{NH}_{4}^{+}$} \\
\hline & 70 & 25 & 69 & \\
\hline & 140 & 22 & 75 & \\
\hline & 210 & 25 & 78 & \\
\hline \multirow{4}{*}{$\begin{array}{l}\text { Mixture/ } \\
\text { Smeša I }\end{array}$} & 0 & 36 & 70 & \\
\hline & 70 & 23 & 75 & \\
\hline & 140 & 30 & 96 & \\
\hline & 210 & 35 & 136 & \\
\hline \multirow{4}{*}{$\begin{array}{l}\text { Mixture/ } \\
\text { Smeša II }\end{array}$} & 0 & 34 & 58 & \\
\hline & 70 & 38 & 62 & \\
\hline & 140 & 32 & 61 & \\
\hline & 210 & 36 & 79 & \\
\hline \multirow{4}{*}{$\begin{array}{l}\text { Mixture/ } \\
\text { Smeša III }\end{array}$} & 0 & 16 & 53 & \\
\hline & 70 & 16 & 57 & \\
\hline & 140 & 32 & 69 & \\
\hline & 210 & 13 & 64 & \\
\hline \multicolumn{2}{|l|}{$\overline{\mathrm{X}}$} & 28 & 73 & \\
\hline
\end{tabular}

By correlation analysis of variable traits dependence between investigated parameters was established (graph 1).

Average value of nitrates in plants in both investigation years and content of nitrate soil in different treatments at the end of trial are in positive correlation $r_{x y}=0,54399$ (graph 1), i.e. with the increase of content of nitrate in soil also the content of nitrate in plant increases, which is in accordance with results obtained by Ilinef (2000).

From results relating to nitrate in soil we can see that values are not negligible and if by precipitation they would be completely washed off, which is highly probable, and considering that analysis was done in autumn, in underground waters higher concentrations above allowed limits would occur 
(Nitrate Directive- 91/676/EEC). Therefore it is necessary to reduce the amount of $\mathrm{N}$ applied with fertilization, and in this way not only the quantity of nitrate in soil would be reduced but also in plant, which is good from the aspect of quality.

Graph 1. Dispersion diagram of dependence of nitrates in plants and soil Grafikon 1. Dijagram raspršenosti zavisnosti nitrata u biljkama i nitrata u zemljištu

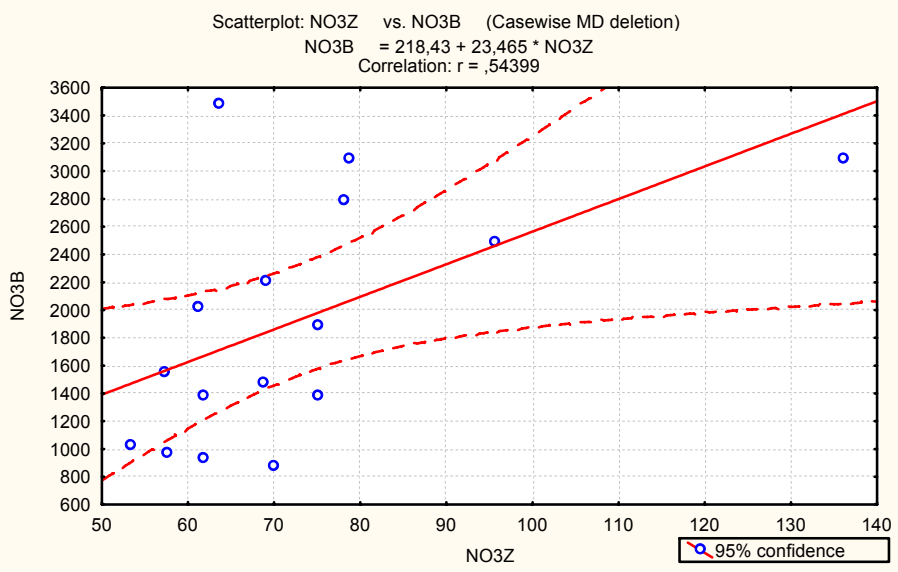

\section{Conclusion}

Content of $\mathrm{NO}_{3}^{-}$in grass-leguminous mixtures in both investigation years is highly dependant on fertilization and interaction of investigated factors.

With the increase of quantity of $\mathrm{N}$ also the content of $\mathrm{NO}^{-}$increases. The highest content of nitrates was established in treatments with $210 \mathrm{kgN} \mathrm{ha}^{-1}$ of $3401 \mathrm{ppm}$ in year 2003 and $2847 \mathrm{ppm}$ in year 2004, whereas the lowest content was established in treatments without $\mathrm{N}$ in both investigation years $1190 \mathrm{ppm}$ and $732 \mathrm{ppm}$, respectively.

In interaction of investigated factors, the highest content was established in mixture of lucerne, cocks foot and tall fescue (II) with $210 \mathrm{kgN}$ $\mathrm{ha}^{-1}$ of $3812 \mathrm{ppm}$ in first investigation year and in the second investigation year mixture with sainfoin (III) with $210 \mathrm{kgN} \mathrm{ha}^{-1}$ of $3479 \mathrm{ppm}$.

Fertilization with $\mathrm{N}$ caused increase of content of $\mathrm{NO}_{3}{ }^{-}$in soil. Content increased in average by $40 \%$ compared to content prior to beginning of trial and varied from $53 \mathrm{ppm}$ in mixture III $0 \mathrm{~N}$ to $136 \mathrm{ppm}$ in mixture I $210 \mathrm{~N}$. 
Between nitrates in plant and nitrates in soil there is positive correlation $r_{x y}=0,54399$, i.e. with the increase of content of nitrates in soil also the content of nitrate in plant increases.

Fertilization of grass-leguminous mixtures with high doses of nitrogen, in general, does not induce accumulation of nitrates in plant above allowed limits, which would cause harmful effect on health condition of livestock, however, these amounts of nutrients added to fertilizer have harmful effect on environment since they cause accumulation of nitrates in soil and pose potential threat/danger of underground and surface water pollution.

\title{
Nitrati u biljci i zemljištu nakon đubrenja travno- leguminoznih smeša
}

\author{
Z. Nešić, Z. Tomić, V. Krnjaja, D. Tomašević
}

\section{Rezime}

Nitrati su jedan od najčešće usvajanih oblika $\mathrm{N}$ iz zemljišta. Preko korena oni dospevaju do stable i lista gde se fotosintetičkim procesima konvertuju u proteine. Usled izloženosti stresnim situacijama, kao i preteranim đubrenjem azotnim đubrivima, dolazi do nagomilavanja nitrata u tkivima $i$ organima biljaka. Pored toga oni se mogu nakupljati u štetnim koncentracijama i u zemljištu. U biljkama nagomilani nitrati imaju štetnog uticaja na životinje, jer ishranom, izazivaju različite zdravstvene poremećaje. Analizom varijanse u obe godine ispitivanja utvrđeno je da su đubrenje kao i interakcija faktora smeša/đubrenje imali vrlo značajnog uticaja na ispitivani parametar kvaliteta, za razliku od smeše kao pojedinačnog faktora. $U$ obe ispitivane godine tretmani sa $210 \mathrm{kgN} \mathrm{ha}^{-1}$ imali su najveću koncentraciju nitrata. Sadržaj nitratnog azota u zemljištu povećava se đubrenjem.Cilj istraživanja je da se utvrdi koje su to količine nitrata koje biljka akumulira nakon đubrenja $\mathrm{N}$ đubrivim i gajenjem $\mathrm{u}$ smeši sa drugim vrstama, kao i koje su to količine nitrata koje ostaju u zemljištu ne iskorišćenje, a koje mogu biti potencionalni zagađivači životne sredine.

Ključne reči: travno-leguminozne smeše, zemljište, nitrat, đubrivo. 


\section{Literature}

ANDRASKI, T.W. and BUNDY, G.L. (2002). Using the presidedress soil nitrate test and organic nitrogen crediting to improve corn nitrogen recomendations. Agronomy Journal, 94, 1411.1418.

EGHBALL, B. (2002). Soil proporties as influenced by phosphorus and nitrogen-based manure and compost applications. Agronomy Journal, 94, 128135.

ELGERSMA, A. and HASSINK, J. (1997). Effect of white clover (Trifolium repens L.) on plant and soil nitrogen and soil organic matter in mixtures with perennial ryegrass (Lolium perenne L.). Plant and Soil, 197, 177-186.

FERGUSON, R.B., HERGERT, W.G., SCHEPEIRS, S.J., GOTWAY, E.J., CAHOON, J.E., PETERSON, A.T. (2002). Site-specific nitrogen management of irrigated maize: Yield and soil residual nitrate effect. Soil Science, 66, 544-553.

HANNAWAY, B.D. and SHULER, E.P. (1993). Nitrogen fertilization in lucerne production. Journal of Production Agriculture, 6, 80-85.

ILIN, Ž., ĐUROVKA, M., MARKOVIĆ, V., LAZIĆ, B., BOŠNJAK, Đ. (2000). Effect of mineral nitrogen concetration in soil and irrigation on $\mathrm{NO}_{3}$ content in pateto tubers. Proc. $8^{\text {th }}$ IS on Timing of field production in vegetables NEŠIĆ Z., TOMIĆ Z., VUČKOVIĆ S., KRNJAJA V., JOSOPOVIĆ S., RUŽIĆ-MUSLIĆ D. (2007). Changes in botanical composition of alfalfa mixtures depending on the species and $\mathrm{n}$ fertilization. $2^{\text {nd }}$ International Congress On Animal Husbandry New Perspectives And Challenges Of Sustainable Livestock Farming. Biotehnology In Animal Husbandry. 23, 5-6 (2), 365-374.

NEŠIĆ Z., TOMIĆ Z., RUŽIĆ-MUSLIĆ D.,VUČKOVIĆ S. (2008). Effects of seed mixture and $\mathrm{N}$ fertilization on nitrate content of grass-legume swards. Biodiversity and Animal Feed. Proceeding of the $22^{\text {nd }}$ General Meeting of European Grassland Federation, 13, 429-431.

PETROVIĆ, N., KASTORI, R. (2003). Nitrati u povrću. Naučni institut za ratarstvo i povrtarstvo Novi Sad, 116

SHIEL, R.S., TILIB, A.B.A., YOUNGER, A. (1999). The influence of fertilizer nitrogen, white clover content and environmental factors on the nitrate content of perennial ryegrass and ryegrass/white clover swards. Grass and Forage Science, 54, 275-285.

STANTON, L.T. (2001). Nitrate poisoning. Colorado State University Extension, No.1.610.

TOTEV, T., MIHOVSKY, TZ., LINGOURSKI, V., TANKOV, K., PAVLOV, D. (1997). The effect of mineral fertilization on the variation in the nitrate concentration of fodder from natural and artificial grass-stands.Biotehnologija $u$ stočarstvu, 245-251.

VOJIN, S., ERIĆ, P., UBAVIĆ, M. (2003). Ishrana biljaka i đubrenje, Poljoprivredni institut, Banja Luka, 169. 